\title{
Melanoma-Associated Antigen 11
}

National Cancer Institute

\section{Source}

National Cancer Institute. Melanoma-Associated Antigen 11. NCI Thesaurus. Code C91338.

Melanoma-associated antigen 11 (429 aa, $48 \mathrm{kDa}$ ) is encoded by the human MAGEA11 gene. This protein is involved in the regulation of androgen receptor activation. 